\title{
MINDFULNESS, SELF-ESTEEM, AND BURNOUT IN COUNSELORS AND PSYCHOLOGISTS WORKING AT SCHOOLS
}

\author{
Gökçe Bulgan \\ Department of Psychological Counseling and Guidance, MEF University (Turkey)
}

\begin{abstract}
Burnout is a struggle of today's workforce and is regarded as a risk factor for mental health professionals working with countless social, emotional, and career related issues. Understanding the role of resources would help with its prevention and early intervention. The aim of this study is to investigate the role of mindfulness and self-esteem as possible resources in relation to burnout in counselors and psychologists working at schools. Data were collected from 338 (229 females and 109 males) counselors and psychologists working at public schools in Turkey, among them 184 (54.4\%) were counselors and 154 (45.6\%) were psychologists. Participants' age ranged between 21 and 51 with a mean of 31.41 $(S D=8.09)$. Data were collected using a Demographic Information Form, and Turkish versions of the Mindful Awareness Attention Scale (Brown \& Ryan, 2003; Özyeşil, Arslan, Kesici, \& Deniz, 2011), the Self-Liking Subscale of the Two Dimensional Self-Esteem: Self-Liking and Self-Competence Scale (Doğan, 2011; Tafarodi \& Swann, 2001), and the Burnout Measure Short Version (Pines, 2005; Tümkaya, Çam, \& Çavuşoğlu, 2009). The internal consistencies of the scales in the current study were $.87, .85$, and .90 respectively. The results indicated no significant differences between the genders of the participants on variables of mindfulness, self-esteem, and burnout. There were significant negative correlations between mental health professionals' mindfulness and burnout levels $(r=-.34 ; \mathrm{p}<.001)$ and their self-esteem and burnout levels $(r=-.53 ; \mathrm{p}<.001)$. In addition, there were positive relationships between mental health professionals' mindfulness and self-esteem levels $(r=.39 ; \mathrm{p}<.001)$. Results of multiple regression analyses indicated that mindfulness and self-esteem accounted for $30.2 \%$ of variance in mental health professionals' burnout levels. In addition, mindfulness $(\beta=-.15, \mathrm{p}<.01)$ and self-esteem $(\beta=-.47, p<.001)$ both uniquely contributed to burnout. Considering that mindfulness and self-esteem had significant unique contributions to burnout, teaching simple yet effective interventions and strategies for increasing mindfulness and self-esteem during their undergraduate program could be useful in preventing counselor and psychologist burnout in later years. As school counselors and psychologists feel more resourceful in preventing and dealing with burnout, they would be more effective in their work with students. Based on the results, the counseling and psychology curriculums could be reconstructed by including courses that focus on mindfulness based practices and those that strengthen one's relationship with himself/herself. Including courses such as positive psychology or increasing happiness and wellbeing could be valuable goals to focus on within the future directions of the counseling field.
\end{abstract}

Keywords: Mindfulness, self-esteem, burnout, mental health, school psychology.

\section{References}

Brown, K. W., \& Ryan, R. M. (2003). The benefits of being present: Mindfulness and its role in psychological well-being. Journal of Personality and Social Psychology, 84, 822-848.

Doğan, T. (2011). İki boyutlu benlik saygısı: Kendini sevme / Öz-yeterlik Ölçeği’nin Türkçe’ye uyarlaması, geçerlik ve güvenirlik çalışması. Eğitim ve Bilim, 36(162), 126-137.

Özyeşil, Z., Arslan, C., Kesici, Ş., \& Deniz, M. E. (2011). Bilinçli Farkındalık Ölçeği’ni Türkçe’ye Uyarlama Çalışması, Eğitim ve Bilim, 36(160), 224-235.

Pines, A. M. (2005). The Burnout Measure Short Version (BMS). International Journal of Stress Management, 12(1), 78-88.

Tarafodi, R. W., \& Swan, W. B. (2001). Two-dimesional self-esteem: Theory and measurement. Personality and Individual Differences, 31, 653-673.

Tümkaya, S., Çam, S., \& Çavuşoğlu, İ. (2009). Tükenmişlik Ölçeği Kısa Versiyonu'nun Türkçe’ye uyarlama, geçerlik ve güvenirlik çalışması. Ç. Ü. Sosyal Bilimler Enstitüsü Dergisi, 18(1), 387-398. 